\title{
До проблеми трансформації форм і способів усної презентації своїх досліджень психологами-науковцями в умовах інформаційного суспільства
}

Анотація. У статті показано, щзо усне оприлюднення психологом-науковцем свойх наукових доробків ставить перед ним нову, пов'язану з розвитком інформаційного суспільства вимогу, а саме опанування презентаційними вміннями. Проведений аналіз літературних джерел з точки зору своєчасності застосування новітніх методів усного представлення та донесення до наукової спільноти результатів своїх наукових досліджень.

3'ясовано, щуо важсливого значення набуває розвиток здатності науковиів успішно презентувати результати власних досліджень, зокрема в усному науковому дискурсі. Згадана здатність передбачає критичне ставлення автора - твория наукового повідомлення - до інформаиії, його вміння рефлексувати думку аудиторії, вибирати оптимальну форму подання результатів власного дослідження, кваліфіковано працювати з текстом. Вміння презентувати власні наукові доробки є одним з важливих елементів психологічної компетентності психолога, щэо забезпечує їхню асиміляцію в наукових колах та творче застосування на практиці.

Ключові слова: інформаційне суспільство, наукова комунікаиія, презентаџія досліджень, науковий дискурс, психологічна компетентність.

Постановка проблеми. Наукова інформація, отримана в результаті наукового пізнання, відіграє важливу роль у розвитку сучасного суспільства. Інформація поширюється певними засобами, методами. Особливе місце в процесі поширення інформації посідає наукова комунікація в умовах інформаційного суспільства. Презентація наукових доробків $є$ одним 3 елементів психологічної компетентності психолога-науковця.

Аналіз останніх досліджень 3 проблеми.

Питанням професійної комунікації психолога присвячені роботи В.В. Андрієвської, зокрема мова й мовлення розглядаються як засоби самопрезентації (у професійному інформаційному полі, у фаховій діяльності, у соціальній комунікації, у повсякденному житті) [2]. У широкому розумінні термін «самопрезентація» означає самопред’явлення, самоподачу. Саме в такому розумінні він найчастіше вживається зарубіжними й вітчизняними фахівцями. Н. Амяга вважає, що, на відміну від саморозкриття, цілі якого різноманітні, метою самопрезентації $є$ управління враженнями аудиторії [1]. Поняття самопрезентації визначається, зокрема, в Оксфордському енциклопедичному словнику з психології таким чином: «Самопрезентація - термін, синонімічний поняттю «управління враженням», служить для позначення численних стратегій, які використовуються людьми 3 метою контролю й управління враженням, яке вони можуть справляти на оточуючих» [1]. За Д. Майєрсом, самопрезентація розшифровується як «акт самовираження й поведінки, спрямований на те, щоб створити сприятливе враження або враження, відповідне чиїмось ідеалам». Самопрезентація являє собою виконання людиною певної ролі, спрямоване на створення певного враження. Дослідження самопрезентації через рольову поведінку представлено у працях I. Гофмана [4]. Ним створена концепція «соціальної драматургії», суть якої полягає в проведенні аналогії між соціальними взаємодіями й театральною виставою. Людина $€$ соціальним актором, що постійно прагне регулювати справлене нею враження на оточуючих. Самопрезентація у цій теорії описана як виконання індивідом певної ролі перед якоюсь конкретною аудиторією, що спочатку готується 3 метою бездоганної реалізації, потім програється в іншому 
оточенні. Деякі дослідники розрізняють такі поняття, як самопред'явлення та саморозкриття. Так, О. Шумейко [7] вважає, що: 1) самопред'явлення і саморозкриття є глибоко взаємопов'язаними, однак протилежними за своєю модальністю структурними компонентами самопрезентації; 2) самопред'явлення та саморозкриття принципово відрізняються за двома критеріями: за специфікою змісту інформації та за метою передачі інформації; 3) проблему самопрезентації запропоновано досліджувати одразу у двох різних контекстах: «самопрезентація як саморозкриття» $\mathrm{i}$ «самопрезентація як самопред’явлення».

Мета даної роботи: проаналізувати сучасні наукові дані, які накопичено в області психології комунікацій, з'ясувати комунікативну специфіку презентації психологами своїх наукових доробків в умовах інформаційного суспільства.

Виклад основного матеріалу дослідження. В сучасній психології існує багато варіантів визначення поняття «інформаційне суспільство», наприклад:

- суспільство, орієнтоване на людей, відкрите для всіх і спрямоване на розвиток, у якому кожний може створювати інформацію i знання, мати до них доступ, користуватися й обмінюватися ними, даючи змогу окремим особам, громадам і народам повною мірою реалізувати свій потенціал, сприяючи своєму невпинному розвитку й підвищуючи якість свого життя;

- суспільство, економіка якого базується на інформаційних технологіях і яке соціально трансформується з метою допомогти індивідам та спільнотам використовувати знання та ідеї, що надає людям можливість втілити їхній потенціал та реалізувати їхні прагнення;

- суспільство, яке створюється внаслідок нової індустріальної революції на базі інформаційних і телекомунікаційних технологій та на базі інформації, яка $є$ виразником знання людей. Завдяки технологічному про- гресу в такому суспільстві оброблення, накопичення, отримання й обмін інформацією в будь-якій іï формі - звуковій, письмовій або візуальній — не обмежені відстанню, часом і обсягами. Ця революція додає великих можливостей людському інтелекту та створює ресурси, що змінюють спосіб суспільної праці і суспільного життя.

Вважається, що в інформаційному суспільстві створення, розповсюдження, використання, узагальнення й маніпулювання інформацією становить значну частину економічної, політичної та культурної діяльності. Економіка знань стає економічною копією цієї діяльності, оскільки добробут суспільства створюється через експлуатацію знань або розуміння суті речей та процесів. Люди, які мають засоби й можливості для участі в такому суспільстві, отримують певні додаткові вигоди, порівняно з тими, хто таких можливостей або засобів не має. «Інформаційне суспільство» вважається наступником «індустріального суспільства». Оскільки сучасні інформаційно-комунікаційні технології працюють 3 інформацією в дискретній, цифровій формі, то часто для позначення «інформаційного суспільства» використовується синонімічний термін «цифрове суспільство», а різницю між членами в можливостях $\mathrm{i}$ засобах участі в такому суспільстві позначають як «цифровий розрив». Визначено велику кількість ознак, які можуть характеризувати настання «інформаційного суспільства». Ознаки нових швидких змін у суспільстві можуть мати технологічний, економічний, праце-орієнтований, просторовий, культурний або комбінований характер. Тісно пов'язаними з концепцією «інформаційного суспільства» $є$ концепції «постіндустріального суспільства» (Деніел Белл), «пост-фордизму», «постмодернізму», «суспільства знань», «телематичного суспільства», «інформаційної революції», «революції білих комірців» та «мережного суспільства».

Глобальне інформаційне суспільство формується локально, у різних країнах 
цей процес іде з різною інтенсивністю й особливостями. Інформаційні товариства мають три головних характеристики. Поперше, інформація використовується як економічний ресурс. Організації використовують інформацію у все більших масштабах з метою підвищити ефективність, стимулювати інновації, укріпити конкурентоспроможність. По-друге, інформація стає предметом масового споживання у населення. По-третє, відбувається інтенсивне формування інформаційного сектору економіки, який зростає швидшими темпами, ніж інші галузі. Причому рух до інформаційного суспільства - загальна тенденція для розвинених держав і країн, що розвиваються.

У теперішній час сфера послуг переважає над промисловістю і сільським господарством. Створення ж інформаційних продуктів і послуг також можна віднести до сфери послуг. Сучасні інформаційні телекомунікаційні технології (ITT) в багато разів збільшили нашу здатність обробляти інформацію і тим самим сприяли зростанню інформаційно насиченого сектору економіки. Концепція постіндустріального суспільства в найзагальнішому вигляді зводиться до того, що залежно від рівня технологій у культурі послідовно переважають: «первинна» сфера діяльності (тобто сільське господарство), вторинна (тобто промисловість) i, нарешті, тепер формується «третинна» сфера діяльності (тобто сфера послуг). Кожній із трьох стадій властиве домінування певних форм соціальних інститутів: в аграрній культурі - це церква й армія, в індустріальній — корпорації, а постіндустріальній - університети та інші наукові заклади. Відповідно елітою для індустріальної аграрної культури $\epsilon$ священики та феодали, індустріальної - бізнесмени, постіндустріальної - учені та спеціалісти-професіонали. Таким чином, домінування третинної сфери діяльності - сфери послуг - закладає основи постіндустріального суспільства, у якому провідну роль відіграють наука й освіта. 3 часом категорія інформації стає ключовим поняттям досліджень постіндустріа- льної культури. У розумінні самого поняття «інформаційне суспільство» можна виділити три основних підходи: технологічний, комунікативний, соцієнтальний.

Поняття «компетентність» можна певною мірою ототожнити 3 поняттям «професіоналізм», коли йдеться про предметну досконалість у будь-якій сфері людської діяльності. Дещо спільне воно має із поняттям «життєва мудрість» як поєднання природного розуму, інтуїції та спостережливості, що надають здатності до розвитку соціального інтелекту, тобто адекватного розуміння психології та поведінки людей у різних соціально-психологічних ситуаціях. Ми розуміємо компетентність як спеціально набуті знання в поєднанні з певними особистісними здібностями, життєвим досвідом та вмінням їх доцільно застосовувати в будь-якій діяльності.

Психологічна компетентність - індивідуальна траєкторія сходження до вершин професіоналізму, де певну роль відіграють ситуації спілкування, професійні психологічні позиції (стійкі системи ставлення до себе, до колег), що визначають поведінку, комунікативні вміння. Важливе значення в практиці психологічної роботи мають мотивація і стимулювання до інноваційної діяльності. Діяльність - спілкування - особистість - професійні знання - психологічні якості — особливості пізнавальної сфери, мислення (для порівняння: технічне мислення, художнє мислення, клінічне мислення лікаря) - все це входить до поняття компетентність. Сюди належать також спостережливість, рефлексія, самооцінка, самопізнання (цілісне бачення самого себе) та особливості мотиваційної сфери. Питома вага складових професійної компетентності неоднакова, все має значення: і майстерність, і володіння психологічними техніками, психологічна етика (дотримання норм спілкування, гуманістичні принципи), психологічна творчість, і особиста позиція. У наукових працях до поняття компетентності включають, крім загальної сукупності знань, ще й знання можливих наслідків конкретного способу впливу, рівень умінь та досвід 
практичного використання знань. Аналізуючи проблеми визначення сутності компетентності, Дж. Равен виділяє 37 iї видів [6]. Звертає на себе увагу широка представленість у різноманітних видах компетентності категорій «готовність», «здатність», а також таких психологічних якостей, як «відповідальність», «упевненість». Як уважає автор, основними складовими компетентності $\epsilon$ внутрішньо вмотивовані характеристики, пов'язані з системою особистісних цінностей (ініціативність, лідерство, безпосередній інтерес до механізмів роботи організації, суспільства загалом, а також до роздумів про можливий уплив на неї саму); уявлення та очікування, пов'язані з механізмами функціонування суспільства та роллю людини в ньому (уявлення особистості про себе й про ту роль, яку вона сама відіграє у суспільстві). За Равеном, компетентність складається iз великої кількості компонентів, багато 3 яких відносно незалежні один від одного; деякі з них належать швидше до когнітивної сфери, а інші - до емоційної, і ці компоненти компетентності можуть значною мірою замінювати один одного як складові ефективної поведінки. Чим більше таких компонентів залучає людина в процес досягнення значущих для себе цілей, тим більша ймовірність, що вона цих цілей доб'ється. Таким чином, Дж. Равен [6] розглядає компетентність як можливість установлення зв'язку між знаннями й ситуацією, як здатність знайти, виявити знання й дію (процедуру), які можна застосувати до розв'язання проблеми (соціальної ситуаціiі).

Головним аспектом, який поєднує точки зору різних авторів, є те, що знання людини виступають як потенціал, який вона має, але застосувати його на практиці можна лише за умови наявності додаткових чинників. Отже, компетентність - це не тільки наявність знань і досвіду, але й уміння їх використовувати, здійснюючи свої професійні функції.

Усний науковий дискурс - це простір для виявлення психологічної компетентності, що відкриває широкі можливості для особистісної самопрезентації, проте в деяких його формах (наукова доповідь) ці можливості використовуються мінімально, в інших (офіційно-публічна дискусія) пізнавальні мотиви переплітаються 3 мотивами особистого статусу та престижу. За характером висловлювання можна простежити, як учасники комунікативного процесу досягають своєї мети, завойовують свою територію, займають своє місце в науковій ієрархії. Отже, уміння публічно подати результати своїх наукових досліджень, зрозуміло та професійно розповісти про них $є$ не менш важливим, ніж самі результати цих досліджень, тому особливе місце в усному науковому дискурсі займає характер презентації автором свого власного наукового доробку.

- Презентація - суспільне оприлюднення чогось нового, щойно створеного.

- Презентація (спосіб надання інформації) - інформаційний чи рекламний інструмент, що дає можливість повідомити важливу інформацію про об'єкт презентації в зручній для адресата формі.

Успішна презентація результатів наукових досліджень забезпечує їх широке оприлюднення в наукових колах і застосування в практиці. Вона виконує три найважливіші функції: ознайомлення і популяризацію науки; встановлення контактів 3 колегами; створення умов для впровадження отриманих розробок в практику. Представлення своїх наукових доробків передбачає також і самопрезентацію автора. Концепції самопрезентації грунтуються на уявленнях про те, що поведінка людини часто змінюється в умовах публічності порівняно з умовами приватності.

Презентація наукових доробків є одним 3 елементів психологічної компетентності психолога. Для проведення наукових презентацій особливе місце займають знання та навички науковців щодо висвітлення обраної теми, результатів своїх досліджень. Зокрема, необхідною умовою $є$ володіння комп'ютерними програмами для обчислення результатів досліджень. У своїй досить 
актуальній роботі «Майстерність презентації» О. Каптєрєв [5] відзначає, що успіх презентації на 90\% залежить від того, чи володіє доповідач прийомами риторики, чи вміє виступати, задавати цікаві питання. Насамперед такі питання мають бути цікавими для доповідача, бо інакше це не буде цікаво нікому і нікого не зачепить. По-друге, звичайно, питання повинні бути цікавими публіці. Далі все залежить від відповідей доповідача на ці питання - наскільки вони будуть доречні. Але навіть якщо відповіді будуть хорошими лише частково, це вже добре, аудиторія зможе зробити для себе відкриття. Презентація насамперед повинна бути цікавою і зрозумілою, а потім вже переконливою. Доповіді мають бути сконцентрованими не тільки на тому, як переконати, а й на тому, як донести результати своїх досліджень цікаво та зрозуміло для аудиторії.

Структура доповідей-презентацій має таку схему: перша частина — вступ, у перебігу якого потрібно налагодити емоційний зв'язок з аудиторією. Друга - постановка питань, загальна проблематизація. Тут необхідно цікаво розповісти про проблему, що висвітлюється. Це мотивувальна частина, і вона найважливіша. Якщо цю частину недостатньо опрацювати, то можна провалити свою презентацію. Третя частина презентація рішення. Вона повинна бути описана логічно і послідовно. Четверта частина - завершення: резюме, ціна питання, заклик до дії. Ціна в підсумку залежить від того, для яких цілей потрібна презентація, багато залежить від тієї користі, яку продуктивна презентація може принести. До проведення презентації зазвичай висуваються наступні вимоги: 1) до змісту — чи $\epsilon$ презентація чітко спланованою, доступною, цікавою для цієї аудиторії? Наскільки достовірними є подані відомості? Чи достатньою $є$ кількість використаних джерел для обгрунтування поданих даних? Чи є актуальними та практично значущими для аудиторії подані повідомлення? Чи грамотно викладені подані відомості? Чи є відповідні висновки, рекомендації? 2) до дизайну — чи добір шрифтів та їхнього розміру сприяє легкості читання та сприйняття, чи відповідає змісту презентації? Чи підкреслює зміст запропонований фон, чи є він самобутнім та психологічно комфортним? Чи використовуються зображення у презентації? Чи опрацьовані вони належним чином? Чи доповнюють зміст використані зображення? Чи використовуються діаграми, графіки, схеми? Наскільки доцільним $\epsilon$ їх добір? Наскільки повно використано можливості анімації? Чи відповідає кількість слайдів презентації розкриттю іï змістової частини відповідно до мети іiі створення?

Власне, існує досить багато розробок, робіт, присвячених тому, як зробити успішною презентацію, які для цього необхідні технічні засоби. Презентація має об'єднувати в собі структуру, драматургію, дизайн і техніку виступу, вимагає майстерності володіння візуальною мовою, щоб домогтися найкращих результатів. Щодо усної презентації своїх наукових доробків, однією з нових вимог інформаційного суспільства $є$ вироблення адекватних презентаційних умінь.

Висновки. Таким чином, беручи до уваги велику кількість інформації, що циркулює в сучасному інформаційному суспільстві, та різні підходи до вказаної теми, можна зробити ряд висновків:

1. Важливого значення набуває розвиток здатності науковців успішно презентувати результати власних досліджень, зокрема в усному науковому дискурсі.

2. Згадана здатність передбачає критичне ставлення автора - творця наукового повідомлення - до інформації, його вміння рефлексувати думку авдиторії, вибирати оптимальну форму подання результатів власного дослідження, кваліфіковано працювати з текстом.

3. Вміння презентувати власні наукові доробки є одним з важливих елементів психологічної компетентності психолога, що забезпечує їх асиміляцію в наукових колах та творче застосування на практиці.

Як показав аналіз літератури, зазначена проблема $є$ малодослідженою i, разом $з$ тим, перспективною щодо розкриття особливостей комунікативної компетентності психолога в умовах інформаційного суспільства. 
Список використаних джерел:

1. Амяга Н.В. Самораскрытие и самопредъявление личности в общении / Н. В. Амяга // Личность. Общение. Групповые процессы. - М., 1991. — С. 37-74.

2. Андрієвська В.В. Діяльність психолога як простір мови і мовлення: проблема інтегральної моделі мовно-мовленнєвої компетентності / В.В. Андрієвська // Наук. зап. Ін-ту психології ім. Г. С. Костюка АПН України / за ред. С. Д. Максименка. - К. : Ніка-Центр, 2009. - Вип. 37. - С. 44-76.

3. Ботіна Л.Й. Гендерні особливості усного наукового мовлення / Л.Й. Ботіна // Наук. зап. Ін-ту психології ім. Г. С. Костюка АПН України / за ред. С. Д. Максименка. - К. : ВД «Троя», 2008. - Вип. 36. - С. 83-93.

4. Гофман И. Представление себя другим в повседневной жизни/И. Гофман. - М., 2000. $-326 \mathrm{c}$.

5. Каптерев А. Мастерство презентациим: как создавать презентации, которые могут изменить мир / А. Каптерев. - М. : Манн, Иванов и Фербер, 2012. - 336 с.

6. Равен Дж. Компетентность в современном обществе: выявление, развитие и реализация / Джон Равен // пер. с англ.. - М. : Когито-центр, 2002. — 396 с.

7. Шумейко О. Поняття «самопрезентація» та «управління враженням» у вітчизняній та зарубіжній соціальній психології [Електронний ресурс] / О. Шумейко. - Режим доступу : http://www.politik.org.ua/vid/magcontent.php3?m=6\&n=76\&c=1832\&setcss=1\&ncss=big

Аннотация. В статье показано, что устное представление психологом-ученым результатов своих научных исследований ставит перед ним новую, связанную с развитием информационного общества задачу, а именно овладение презентационными умениями. Проведен анализ научных литературных источников с точки зрения своевременности и актуальности использования новейших методов устного представления и донесения научному сообществу результатов своих исследований.

Выяснено, что большое значение имеет развитие умений исследователей осуществлять презентацию результатов собственных достижений, а именно в научном дискурсе. Данные умения предусматривают критическое отношение автора - создателя научного доклада - к освещяемой информации, его умения рефлексировать мнения аудитории, выбирать наиболее удачную форму подачи результатов собственных исследований, квалифицированно работать с текстом. Умения презентовать собственные научные достижения является одним из важнейших элементов психологической компетентности психологов, обеспечивающее их ассимиляцию в научных кругах и творческое применение в практике выступлений.

Ключевые слова: информационное общество, научная коммуникация, презентация исследований, научный дискурс, психологическая компетентность.

Abstract. The article provides the analysis of modern scientific data, which was gathered in the sphere of psychological communications concerning the presentation of scientific knowledge by psychologist-scientists.

The article highlights that the oral presentment of a psychologist-scientist his scientific results sets the requirement connected with the development of informational society which is to acquire the presentation skills. The literature review was conducted from the point of view of the prompt usage of oral presentation modern methods and introduction own results to scientific society.

It is determined that the development of scientist's ability to present own research results in oral scientific discourse in particular is of great importance. Mentioned ability comprises critical attitude of the author-creator of a scientific message to the information, his ability to reflect the opinion of the audience, choose the appropriate form of presentment of own research results, work with the text competently. The ability to present own scientific progress is one of the most important elements of psychological competence of a psychologist, that ensures its assimilation among scientists and creative practical appliance.

The article stages that the ability to introduce own scientific progress in public, give the information clearly and professionally isn't of less importance than the research results. That is why the manner of presentation of own scientific progress occupies a special place in oral scientific discourse.

The article presents the influence of informational society on the formation and development of presentational competences of psychologist-scientists.

According to the literature review and our research the problem mentioned in the article is understudied, and, at the same time, it is promising concerning the development of peculiarities of communicative competence of a psychologist under the conditions of informational society.

Keywords: Informational society, scientific communication, research presentation, scientific discourse, psychological competence. 